\title{
Inorganic solid wastes from agrosilvopastoral sector in Ceres, Goiás, Brazil
}

\author{
Resíduos sólidos inorgânicos do setor agrossilvopastoril em \\ Ceres, Goiás, Brasil
}

Ana Paula Veloso de Assis Sousa ${ }^{a}$

Renato Rosseto ${ }^{b}$

Izabel Cristina Bruno Bacellar Zanetic

Josana de Castro Peixoto ${ }^{d}$

Lucimar Pinheiro Rosseto

${ }^{a}$ Laboratório de Pesquisa em Biodiversidade (LaPeBio), Centro Universitário de Anápolis, UniEVANGËLICA, Anápolis, GO, Brasil

E-mail: anapaulavsousa@hotmail.com

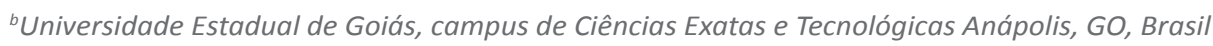
E-mail: renato.rosseto@ueg.br

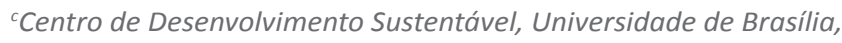
Brasilia, DF, Brasil.

E-mail: izabel.zaneti@yahoo.com

'Laboratório de Pesquisa em Biodiversidade (LaPeBio), Centro Universitário de Anápolis, UniEVANGËLICA, Anápolis, GO, Brasil; Campus de Ciências Exatas e Tecnológicas, Universidade Estadual de Goiás, Anápolis, GO, Brasil E-mail: josana.peixoto@unievangelica.edu.br

eLaboratório de Pesquisa em Biodiversidade (LaPeBio), Centro Universitário de Anápolis UniEVANGËLICA, Anápolis GO, Brasil

E-mail: lucimar.pinheiro@yahoo.com.br

doi:10.18472/SustDeb.v10n3.2019.23868

Received: 31/03/2019

Accepted: 02/12/2019

ARTICLE-DOSSIER

\section{ABSTRACT}

This study aimed to verify the application of available legislation about to the production, quantity and appropriate disposal of inorganic solid wastes from agrosilvopastoral activities in Ceres/GO. The research had a descriptive character, with bibliographic, documentary and field research methods, based on quali-quantitative approaches, and the gathering of primary and secondary data. The data were 
extracted from official records and websites, including information of public and private institutions, and sourced by professional entities and associations responsible for collection, sorting, recycling and final disposal of solid wastes. On the basis of the obtained information, although Ceres/GO city has a small rural population, it was considered as good study model. The efforts and experiences carried out in Brazil and different countries gives us insights to understand and propose solutions related to the waste management from agrosilvopastoral system in Ceres/GO, which may be expanded into other Brazilian cities.

Keywords: Forest Code. Preservation Areas. Deforestation.

\section{RESUMO}

Este estudo teve como objetivo verificar a aplicação da legislação disponível, quanto à produção, quantidade e disposição adequada de resíduos sólidos inorgânicos de atividades agrossilvipastoris em Ceres/GO. A pesquisa teve caráter descritivo, com métodos de pesquisa bibliográfica, documental e de campo, com base em abordagens quali-quantitativas e coleta de dados primários e secundários. Os dados foram extraídos de registros e sítios oficiais, incluindo informações de instituições públicas e privadas, e obtidos por entidades e associações profissionais responsáveis pela coleta, triagem, reciclagem e disposição final de resíduos sólidos. Baseado nas informações obtidas, a cidade de Ceres/ GO, embora tenha uma pequena população rural, foi considerada um bom modelo de estudo. Os esforços e experiências realizados no Brasil e em diferentes países fornecem subsídios para entender e propor soluções relacionadas à gestão de resíduos do sistema agrossilvipastoril de Ceres/GO, que podem ser expandidas para outras cidades brasileiras.

Palavras-Chave: Atividades agroflorestais. Gestão de resíduos. Política nacional de resíduos sólidos. Vale do São Patrício.

\section{INTRODUCTION}

The agrosilvopastoral activities are considered to be one of the oldest of in the entire planet and for this they are responsible for feeding both people and animals. But, just like urban activities, the agrosilvopastoral activities also generate solid waste and pollution. In order to fulfill their goal, these activities are increasingly making use of new technologies in an attempt to generate more productivity and correct soils for certain crops or pastures through the use of chemicals, pesticides or fertilizers. As a result, soil impoverishment occurs due to loss of biodiversity, excess of harmful chemicals to soil and water, which also changes the food chain of animals (DUDLEY et at., 2017; BRÜHL e ZALLER, 2019).

The use of chemicals, pesticides and fertilizers has been generating debates about the effects of their use, both on nature and especially on humans. In the work entitled Challenges Of Family Farmers In The Cruzeiro Dos Martírios And Paulista Rural Communities, Silva e Mendes (2012) conduct a data collection on the disposal of solid waste in these communities, from the municipality of Catalão/GO, and about its effects on small farmers, as did by Godecke e Toledo (2015) in the research entitled: Reverse Logistics of pesticide packaging: a case study of Pelotas/RS. Although Brazil is a country where the agricultural economy predominates, studies that address the collection and disposal of inorganic solid waste (ISW) from these activities are still in the embryonic phase, with few articles published.

The Federal Constitution of 1988, in its Articles 184 to 191, deals with the Brazilian agricultural policy, regulated by Law No. 8.171/1999, which provides for the fulfillment of social function from rural properties, which implies its rational and appropriate use, that its, the proper use of available natural resources, the preservation of the environment, and also the compliance with labor legislation and exploitation aiming at the well-being of the owners and workers (BRAZIL, 1988). Agrosilvopastoral activities and agricultural soil are still supported and regulated by Law No. 12,651 / 2012 of the new Forest Code (BRAZIL, 2012). 
Law no. 12,305/2010 regarding the National Solid Waste Policy (PNRS) seeks to minimize the impact of waste both on the health of living beings and on the environment. In its article 13, item I, letter " $\mathrm{i}$ ", this Law classifies as agrosilvopastoral residues those that are generated in agricultural and silvicultural activities, as well as those related to the inputs used in these processes. Such residues are divided into organic and inorganic, the latter being basically composed of pesticide packaging, fertilizers, veterinary pharmaceutical inputs, and other rural household solid waste (BRAZIL, 2010).

From these mentioned products, only pesticide packaging, its components and the like, have specific disposals established by Law No. 7802/1989, regulated by Decree no. 4.070, of January 4, 2002 (BRAZIL, 2002). This led to more satisfactory results regarding joint liability between the manufacturer, trader and farmer, according to data collected from the National Institute for Processing Empty Packages (inpEV, 2018).

In this sense, this article verifies the application of the available legislation and the understanding of the rural population of Ceres/GO regarding the management and responsibility for the ISW that is produced. Ceres is an inland city located in the state of Goiás where the rural population is mostly made up of small producers, and today it represents less than $5 \%$ of the total population of the municipality, as in most of the country (IBGE, 2010).

\section{METHODOLOGY AND STUDY AREA}

Type of study: we refer to a descriptive research, with bibliographic, documentary and field research methods, qualitative and quantitative approach and primary and secondary data collection.

Bibliographic and documentary research: The databases used in this study were: a) Official data and technical reports from the Ministry of Agriculture, Livestock and Supply (MAPA), Ministry of the Environment (MMA), Brazilian Institute of Geography and Statistics (IBGE), Funding Officer for Studies and Projects (FINEP), b) Documents published annually by the Brazilian Association of Public Cleaning and Special Waste Companies (ABRELPE); c) Non-profit entities such as the National Institute for Processing Empty Packages (inpEV), National Association for Fertilizer Diffusion (ANDA), National Union of Products for Animal Health Industry (SINDAN); d) Solid waste management plans and reports from municipalities, states and the Union.

Data collection was obtained through the analysis of the documents presented by the Secretariat of Environment of the municipality of Ceres/GO, as well as the Rural Management of Ceres/GO and the Municipal Council of Sustainable Rural Development in order to identify the amount, type, the form of disposal, and other information related to the management of agrosilvopastoral solid waste.

Field research: The field research was conducted in 2016 at the inorganic solid waste management company ARIARCER (Ceres Regional Agricultural Input Resellers Association) and also with farmers and traders of agroforestry products located in Ceres/GO.

The instrument used for data collection was a semi-structured interview, having as population the owners of the rural area of Ceres/GO. In total, 86 farmers were interviewed directly on their properties. To calculate the number of rural properties to be searched, the following formula was used:

$$
n=N \cdot z 2 \cdot p \cdot(1-p) \text { z2.p.(1-p)+e2.(N-1) }
$$

Here, $\mathbf{n}$ represents the calculated sample, while $\mathbf{N}$ represents the population, whereas $\mathbf{z}$ was the standardized normal variable associated with the confidence level, and $\mathbf{p}$ constitutes the true probability of the event as well as the sampling error (HOLFFMANN, 2002). For a number of 565 rural properties with $95 \%$ confidence and $10 \%$ sampling error, a sample of 86 rural properties was obtained. 
This field research was also carried out with traders of agricultural and veterinary products in the municipality of Ceres. Six agricultural and veterinary trade companies were selected to participate in this study. For data collection, we also used a semi-structured interview applied to managers of companies that work with products used in agrosilvopastoral activities.

The interviews were conducted following all ethical procedures. All participants read and signed the Informed Consent Form, which contains the description of the study objectives, risks, benefits and also regarding the confidentiality of responses.

Analysis and interpretation of results: The information was treated from a qualitative perspective, through an exploratory analysis and followed the categorization criteria (BARDIN, 2011). Issues related to economic activity, inputs used in rural properties, collection and disposal of ISW packaging and the participation of public authorities in the collection and awareness of the disposal of these wastes were the categories of analysis used to interview the 86 rural landowners in Ceres/GO. For the traders of agricultural and veterinary products in the city of Ceres/GO, the categories analyzed were: the health and work process, the representation of the risk to health and the environment, as well as verifying the destination of the RSI from these products.

Study Area: Ceres is located $173 \mathrm{~km}$ from the capital of the state of Goiás, which is Goiânia, and is also 293km from the Federal District, in the Center of Goiás Mesoregion, which also include Anápolis, Anicuns, Goiânia and Iporá (Figure 1). The Microregion of Ceres is limited to the municipalities of Carmo do Rio Verde, Ipiranga de Goiás, Rialma and Rubiataba. In order to foster sustainable rural development, the territory of the São Patrício Valley was created in 2006 in which Ceres is located today.

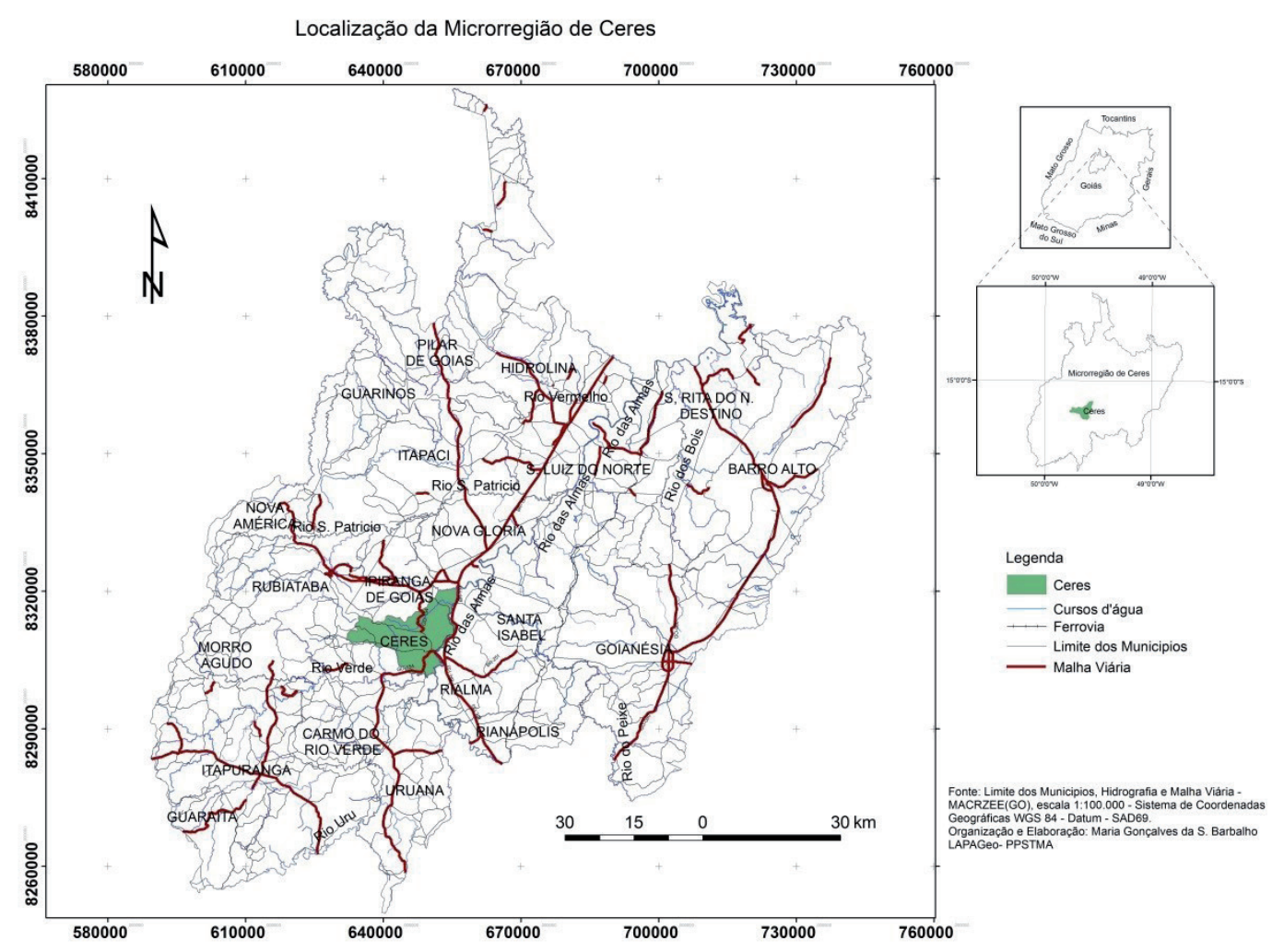

Figure 1 | Geographic localization of the municipality of Ceres, Goiás, Brazil. Source: Barbalho (2019).

Ceres has Aw-type climate - warm and semi-humid - according to the Koeppen classification, with two well defined seasons: the rainy season in the period spanning from November to April, also including a hot rainy summer, with the dry season which runs from May to October. The municipality is located in 
the Morphostructural Domain III: Neoproterozoic Mobile Belts from Central Brazil, Ceres Intermontane Depression. The terrain is wavy, formed by elevations and hills, with emphasis on the Serra da União, Javaés, Taboca and Fartura, and also has declivities with values above $12 \%$ (CERES, 2013).

Inserted in the Cerrado Biome, in the region where Ceres is located, prevails a vegetation of Seasonal Semideciduous Forest and only part Deciduous with the predominance of dry gallery forest. It also has $15 \%$ of the native forests found where the relief is most pronounced, and they are located in the region of the Barro Alto Ultrabasic Basic Complex. Due to the Vulcano-sedimentary structure, the municipality's soil is of the typical Eutroferric Red Nitosol type with a very clayey texture (CERES, 2013).

\section{RESULTS AND DISCUSSION}

\subsection{MANAGEMENT OF INORGANIC SOLID WASTE (ISW) CARRIED OUT BY AGROSILVOPASTORAL TRADERS IN THE CERES REGION/GO}

The city that was born of an agricultural colony and was also named after the Greek goddess Ceres, its aptitude for agriculture did not survive the lack of public policies aimed at the small and medium producer. The municipality now has almost $96 \%$ of its population in the urban area (PERS/GO, 2017), which is a characteristic of most cities in Brazil (IBGE, 2010). The municipality of Ceres is divided into 8 microregions: Córrego do Alegrete, Córrego Fundo, Córrego do Palmital, Córrego da Fartura, Córrego Bom Sucesso/Poção, Córrego da Gameleira, Airport and Córrego do Sapé (CERES, 2013). In these microregions are distributed the 955 inhabitants of rural Ceres, according to data from the Rural Development Management in 2013, predominating people aged over 61 years and incomplete elementary school (52\%).

In addition, this population is also distributed over 565 rural properties. Most of these properties have a size of up to 6 bushels, predominantly in poultry and cattle raising (CERES, 2013).

In this study, field research was carried out at the sites that create, manage, process, supervise and dispose of ISW that comes from agrosilvopastoral activities in Ceres/GO.

Regarding the case of traders of agricultural and veterinary inputs from the municipality of Ceres/ GO who were surveyed, a semi-structured interview was used as a data collection instrument. For this interview, three categories of analysis were grouped, which were based on questions related to the health and work process, the representation of the risk to workers' health and the environment, and to verify the destination of the ISW from these products. Among the six companies, only one has the permission of the Ministry of Agriculture, Livestock and Supply (MAPA) to market pesticides, and, that same company also sells fertilizers and veterinary products. The others sell only fertilizers and veterinary products.

Regarding the health and work process, it was observed that the traders of agricultural and veterinary inputs from the municipality of Ceres/GO are aware of the need for control and disposal of the ISW, and they attribute the low collection of these residues to the lack of control by both the responsible by the production chain, as to the lack of supervision; It was also possible to verify that agrosilvopastoral products are indicated by agronomists through prescriptions, but the applications of the products are at the discretion of rural producers.

Now, regarding the health risk to workers and to the environment, all related traders, during an interview, advise farmers on the correct application of marketed products and on the need to use appropriate safety equipment. However, they stated that most farmers do not wear personal protective equipment (PPE) exhibit the following symptoms: headache, dizziness, itching, blurred vision, tremors, sadness, tiredness, stomach ache, and burning in skin, eyes and nose. 
Regulatory Standard No. 31 (NR 31), issued by the Ministry of Labor and Employment, establishes the requirement for training and use of PPE by rural workers. It aims to establish the precepts to be observed in the workplace, the planning and development of agriculture, livestock, forestry and aquaculture activities with safety and health and the work environment (MET, 2018). As a consequence of non-compliance with NR 31, studies related to pesticide poisoning in rural workers can be found (MONQUERO, INÁCIO and SILVA, 2009; KLEIN et. Al., 2018).

Regarding the provision of the ISW, traders advise consumers on the need for treatment and return of pesticide packaging, in addition to inform that there is a deposit to receive them in Ceres/GO, called ARIARCER (Ceres Regional Agricultural Input Resellers Association). ARIARCER manages both the amount of sales of pesticides and fertilizers, as well as the effective return of packaging that will be made by the farmer upon presentation of the invoice. Every three months, on average, empty packages are placed in larger packages called big bags and upon request to inpEV, which issues the inpEV Collection Order $(\mathrm{OCl})$, releasing the freight, the packages are forwarded to Goianésia/GO receiving center that forwards them to inpEV, finally going to their last destination, directing them for recycling or incineration (inpEV, 2018).

During the technical visit, it was found that ARIARCER complies with the requirements of Resolution No. 465/2014 of the National Environmental Council (CONAMA, 2014), which provides for the minimum technical requirements and criteria necessary for the environmental licensing of establishments destined to receive pesticide and similar packaging, the ones that are empty or containing waste. The criteria are met both in its structure, as in identification with signposts warning about risks and about restricted access only to authorized persons. Right at the entrance of the post there is an office which clearly shows the operating permits issued by the Fire Department, Agrodefense, City Hall of Ceres/GO, plus the name of the current agronomist in charge. In a building separate from the office there is the warehouse that receives the packaging in a dry, closed, but airy environment, far from watercourses and the urban center, and is installed at the industrial sector of Ceres/GO.

It was confirmed in loco that employees make use of PPE, indispensable tools for handling and storage of packaging at ARIARCER. Before receiving the packages, the worker in charge checks that they match the invoice presented by the landowner, and also certify if they have lids and if the triple wash was performed (rinsing of washable pesticide packaging). It was also verified that when receiving the packages, the employee classifies and separates them, noting in the delivery report the amount of clean plastic packaging, the ones that were contaminated, the metallic ones, the flexible ones and others such as cardboard-made ones.

We could not get access to official data on the use and consumption of pesticides in Ceres/GO, given that trade, at the single authorized shop in the city, is offered for the whole region of the Vale do São Patrício. Therefore, it was not possible to verify the amount of pesticides, as well as the amount of other agrosilvopastoral inputs consumed in Ceres/GO.

\subsection{ISW MANAGEMENT PERFORMED BY THE RURAL PRODUCERS OF CERES/GO}

The script that was used for the semi-structured interview was based on questions related to the economic activity carried out in the region, the inputs used on rural properties, the collection and disposal of ISW packaging and the participation of the government in both collecting and raising awareness about the region. the disposal of these wastes together with the rural community of Ceres/GO.

When asked which agricultural inputs are most consumed on their farms, farmers stated that because they carry out more than one productive activity, they make use of various inputs such as: pesticides, fertilizers and veterinary drugs. Thus it was found that $90.6 \%(78)$ rural producers use pesticides; $91.8 \%$ (79) use fertilizers and fertilizers; $88.3 \%$ (76) use veterinary pharmaceutical products and $15.1 \%$ (13) rural producers, usually those who have vegetable production as their economic source, use organic fertilizers such as cattle manure and sugarcane bagasse. 
Farmers were also asked about the disposal of pesticide packaging, and it was found that the manner in which the packaging was disposed of, depended on how the product was purchased in the first place. For example, farmers who purchase the pesticide without the invoice $(6 \%)$ often end up buying small portions from those who bought in larger quantities, despite doing the triple washing of the pesticide packaging, they still keep them on their properties because the returning process must occur through proof of sale, so they use more than one form of disposal. Of those who were interviewed, $28.2 \%$ (22) do the triple washing of pesticide packages and forward them to the warehouse managed by ARIARCER; $10.3 \%$ (8) do the triple washing of pesticide packages, but do not properly dispose of them and keep them on the property; $61.5 \%$ (48) of landowners reported that packages are incinerated or thrown into ditches.

Even counting on a reception station for pesticide packaging in Ceres, it can be seen that $71.8 \%$ of the farmers surveyed do not provide the correct destination for the packages. One of the reasons to be considered is the lack of knowledge and awareness about the environmental damage caused by the improper disposal of agrosilvopastoral solid waste. Of those interviewed in Ceres, $89.5 \%$ answered that they did not participate in debates, lectures or courses that deals with the importance of proper disposal of agrosilvopastoral solid waste and the responsibility of the rural producer.

Comparatively, in a research that was conducted in Rio Grande do Sul, it was found that there is no regulation able to monitor the sale of these products on the Internet and through unregistered merchants. Thus, notably $5 \%$ of the packages of the marketed product do not reach the inpEV receiving center (GODECK and TOLEDO, 2015). This amount is similar to the number obtained in Ceres/GO.

Schmidt and Godinho (2006) encountered technical difficulties faced by farmers in an agricultural cooperative in the countryside of São Paulo, including the disposal of pesticide packaging. In Catalão/ $\mathrm{GO}$ it was found that among the farmers of Cruzeiro dos Martírios and Paulista communities, the percentage of $69.7 \%$ opted for burning and $17.8 \%$ burned and buried the waste, while the rest was abandoned or deposited in holes. (SILVA and MENDES, 2012).

In order to comply with what was determined by Law no.12.305/2010, Ceres hosts (and is a member of) the Inter-municipal Development Consortium of the São Patrício Region (CIDERSP) which prepared the Inter-municipal Plan for Integrated Solid Waste Management in 2013 (CIDERSP, 2013). Under this plan, health care waste must be incinerated by INDCON AMBIENTAL, which treats and disposes of industrial and hospital waste, and is hired by health care providers, not including veterinary health services for which there is no specific collection estimation.

Concerning pesticide packaging, the Intermunicipal Plan for Integrated Solid Waste Management provides that it will be collected by farmers and transported to ARIARCER, which will forward such waste to the Goiás Agricultural Input Distributors Association - ADIAGO, in Morrinhos, which, in turn, will carry out the packaging pressing process for later proper disposal of waste (CIDERSP, 2013).

Thus, it was possible to observe, in this research, the existence of several solid residues in rural areas, both from agrosilvopastoral activities and from domestic activities. Regarding the packaging of pesticides, it could be seen that the rural producer already has knowledge of the need for triple washing and return of packaging, due to reverse logistics, but this professional is not yet aware of his responsibility in the reverse logistics chain.

The landowners from Ceres/GO reuse the vast majority of fertilizer packaging to bag manure, sawdust and other waste. These packages are also used to bag maize or other grains that are produced, and in this case most farmers use them for more than one function: $34.1 \%$ (27) of those using fertilizer donate fertilizer packaging for recycling; $60.4 \%$ (52) reuse fertilizer packaging for bagging manure, sawdust and stones; $66.2 \%$ (57) reuse fertilizer packaging to bag grain such as maize; $72 \%$ (62) of landowners burn fertilizer containers. These characteristics are also observed in other Brazilian locations (IPEA, 2013). 
It appears that farmers are completely unaware of the implications of improper disposal, and without any technical guidance, they give these packages the destination that suits them best. Usually, when farmers do not reuse them, they are burned. The fact that there is no specific legislation for fertilizer packaging, which is not even included in the hazardous waste list, allows the farmer to dispose of it in a similar way to any other packaging generated by his activities.

Among the 86 farmers interviewed, 76 confirmed to use veterinary products. This information, when confronted with data on the activities practiced by farmers, becomes incongruent, given that 80 of the interviewed declared to practice agriculture and among them, 30 also practice poultry farming. From the analysis of these numbers it is clear that probably more people are using veterinary products or animal health is not getting proper attention.

Now, regarding the destination of the packaging of veterinary pharmaceutical products, it has been found that, just as they do with the packaging of pesticides and fertilizers, farmers also use more than one mode of disposal for these wastes. From a total of 76 farmers who said they used veterinary pharmaceutical products, $13.9 \%$ (12) said they returned the packaging in which they purchased the product. When they are unable to return them, so that they do not remain in the properties, they dispose of them in containers that are left in the city and are later sent to the dump ground. However, the Ceres/GO landfill is still under implementation (CIDERSP, 2013); Nevertheless, 76.7\% (66) of rural producers discard packaging into ditches; $73.2 \%$ (63) burn this waste and $12.7 \%$ (11) of farmers said they simply discard packaging in the wild.

It is then observed that the packaging of veterinary products is not properly disposed of. Only twelve (12) landowners said they returned the packaging, the other ones discarded or burned them along with the household waste on their properties, some still dispose of them in the open nature. It is important to note that there is no application of reverse logistics to the packaging of veterinary pharmaceutical products, and the legislation regarding human pharmaceuticals does not even apply to these residues.

During 2018, the animal health products market moved $\mathrm{R} \$ 5.95$ billion, which reflects a growth close to $10 \%$ compared to 2017 (SINDAN, 2018). By way of example, cattle raising, with a herd of approximately 215 million head (ABIEC, 2019), handled over 53\% of this trade with antiparasitic, vaccines, antimicrobials and others (SINDAN 2018), thus making it clear that ISW produced through the use of veterinary drugs is not negligible.

It is important to note the different ways responsible for treating human drugs and veterinary drugs. Although both are considered hazardous waste, the manner of disposal and the relevant legislation, as well as the supervision, are completely differentiated, especially regarding the use of veterinary drugs in rural areas, which are handled by the farmer himself.

Among the veterinary pharmaceutical products there are also those whose function is pesticides, which are composed from the same elements that produce the agrochemicals. But while pesticides are subject to analysis by the Ministry of Agriculture, Livestock and Supply (MAPA), the National Health Surveillance Agency (ANVISA) and the Brazilian Institute of Environment and Renewable Natural Resources (IBAMA), agrochemicals used as veterinary products are controlled by MAPA only.

The diligence given to ISWs originating from agrosilvopastoral activities in Ceres/GO resembles that of other municipalities in the state, as revealed in a survey for the elaboration of the Cachoeira Alta/GO Integrated Solid Waste Management Plan (PGIRS) in 2014. In this municipality, most landowners burn or bury the waste on their property. Those who dispose them for public collection take the waste in their own vehicles when they go to urban centers or deposit it directly in the dump (PGIRS/Cachoeira Alta, 2014).

The finding made by the PGIRS elaborators of Cachoeira Alta/GO regarding the waste produced in the rural area is the same as in Ceres/GO. Only a small number of farmers, notably those living near the 
perimeter, dispose of the waste for public collection, the vast majority discarding waste and tailings on their open-pit properties, in ditches or burning them.

Transporting ISW in personal vehicles is not consistent with the Normative Instruction No. 17/2012 from the Goiás Environment Secretariat, which provides for licensing for the transportation of special and hazardous waste within the State. (Alta Waterfall, 2012).

The rural producers of Ceres/GO were also asked about the existence of environmental education regarding the collection and disposal of ISW packaging. It was found that there is no real concern on the part of the government, with the education and environmental awareness of the population of rural areas. In this study it was also possible to verify that farmers do not know how to properly dispose of waste and tailings produced on their properties. They demonstrated not having enough knowledge about their responsibilities for proper disposal of packaging, as $89.5 \%$ answered not having participated in debates, lectures or courses that dealt with this theme and $91 \%$ of them answered that there is no selective garbage collection, and the disposal is carried out indiscriminately on properties along with household or incinerated waste.

Landowners (95.3\%) are responsible for waste and tailings collection and are not supported by the government, and they do not even have adequate vehicles to transport this waste. The responsibility for the preparation of the management plan, according to art. 20, b, V of Law No. 12,305/2010, is the rural owner who has no such clarification. Thus, it is necessary, also, the action of society and the public power, both in the availability of mechanisms that favor the collection, but also in the provision of environmental education services.

In this research it was possible to conclude that, despite the institutionalized lack of environmental education in Ceres/GO, farmers understand that the destination of ISW in their properties is not adequate. Of the total interviewed, $70.9 \%$ had the notion that the most ideal measure would be the collection of waste produced in rural areas. But due to lack of choice or knowledge about the proper disposal of waste and tailings, these producers do not perform the most environmentally correct management.

The municipality of Ceres/GO currently has a Selective Collection Program for Recyclable Materials that are sent to the Vale do São Patrício Waste Pickers' Cooperative (COTRESP). This program is in its initial phase of managing the activities developed. Although these services are only available to the urban area, not serving rural residents, it can be considered as one of the solutions and/or an environmentally viable alternative for packaging that cannot be reused by the rural producer (CERES, 2013).

This research faced some obstacles in view of the distrust of landowners, who were not comfortable answering the questions posed to them. In order to overcome this obstacle, it was necessary to have the help of an agronomist known to the landowners who accompanied the research and facilitated our contact with them.

\subsection{ALTERNATIVES FOR IMPROVING INORGANIC SOLID WASTE (ISW) MANAGEMENT ACTIONS}

The Ceres/GO Integrated Solid Waste Management Plan (PGIRS) has a description of ISW agrosilvopastoris and is being implemented, although it does not provide any prediction for the management of this waste, something that led to the necessity to compare it with solid waste management plans from other cities in Brazil and the world.

The PGIRS of the municipality of Valinhos/SP does not address the residues from agrosilvopastoral activities, indicating only that such residues "are in charge of those responsible for the processes that generate them" (PGIRS/VALINHOS, 2018). 
In Paulínia/SP, the PGIRS only gives a description of what agrosilvopastoral waste is and has its reception station for pesticide packaging in Valinhos/SP. Moreover, the municipality has a landfill managed by the company ESTRE Ambiental AS - Company for Sanitation and Waste Treatment (PMGRS/PAULÍNIA, 2015).

The warehouse built to collect pesticide residues from Mineiros/GO also receives vaccines and animal medicine packages that are almost entirely delivered to the warehouse of ARDEMI - Association of Mining Defensive Dealers (PGIRS/MINEIROS, 2013).

In Brazil, it is not new to import as management models those that are practiced in Europe and other countries, as it appears in a Technical Note to the Chamber of Deputies in Brasília/DF entitled "Solid Waste Legislation: Comparison of Law no. 12.305/2010 with the legislation of developed countries", which brings experiences and the motto of the legislation coming from countries such as Germany, France, Spain, United States and Canada (JURAS, 2012).

In Germany, since 1994, the "Act for Promoting Closed Substance Cycle Waste Management and Ensuring Environmentally Compatible Waste Disposal" came into force, which has been responsible for extending the manufacturer's responsibility throughout the entire life cycle of its product from the distribution until its elimination. From 2009, phytosanitary products began to be marketed after a rigorous analysis addressing their harmful effects on the environment and on living beings. In addition, most municipal authorities offer a small quantity collection service for these products (JURAS, 2005).

In Prince Edward Island, Canada, for pesticide packaging, the triple wash method is used, followed by devolution to the dealer, and manufacturers and middlemen have a collection and recycling program, since the burning of these packages is prohibited by law. Paper containers that cannot be recycled must be taken to a landfill that is regulated by the Department of Fisheries, Aquaculture and the Environment. Doubts about the use of pesticides or pesticides are resolved by the provincial regulators (CANADA, 2015).

On the other hand, Switzerland charges 35-liter bags at a cost of between 2 and 3 Swiss Francs (SFr). This encourages the population to separate recyclable waste from those that include biological treatment (composting), thereby reducing public spending on waste collection. The country also subsidizes solid waste management including selective waste collection costs for each product traded, which eventually turns into an early fee for product recycling. The costs generated by landfills are borne by their operator (MANNARINO, FERREIRA and GANDOLLA, 2016).

By looking at the experiences of other municipalities and countries, it is possible to realize that the policies regarding the collection of ISW in Ceres is still in its implementation phase. All residues from agrosilvopastoral activities are subject to the practices of the sectoral agreement on pesticide packaging, not reaching residues from veterinary drugs or fertilizers. The selective collection of ISW is not regionally comprehensive, nor is it performed from house to house. Besides that, the municipality has only one truck for selective collection. The distribution of collectors is carried out in some avenues and strategic locations to the population, which has not yet undergone through a significant change caused by environmental education.

Even with the obligation to deliver the pesticide packaging to the dealer, in Ceres, as in the rest of the country, there is no sanction for the consumer that fails to return it, which makes this act linked to the farmers' environmental awareness, since, on being asked about their participation in debates or discussions regarding disposal of inorganic solid waste, $89.5 \%$ of respondents admitted that they did not participate.

Despite the problems faced by the collection and disposal of ISW arising from agrosilvopastoral activities in the city of Ceres, it is possible to apply the experiences from other municipalities, such as Valinhos/ $\mathrm{SP}$ and Mineiros/SP, as well as the disposal systems coming from developed countries such as Germany and the USA, which have distinct solid waste management profiles. 
However, we can see the advancement of Brazilian legislation pertaining to solid waste, including those arising from agrosilvopastoral activities. But the need for progress in this area was also evident. The satisfactory results from the application of Law no. 7,802/1989, based on data collected from inpEV, are due to a sectoral agreement that has been shown to be effective, as well as the implementation of some solid waste management plans, notably PGIRS, from the municipality of Valinhos/SP, which, in addition to providing for a farmer awareness and guidance program, also has a prediction regarding the collection of pesticide packaging and other inputs.

Thus, it is evident the possibility of the verified experiences to be used in the problems arising from the generation of ISW in the rural area of Ceres / GO and other Brazilian municipalities that resemble it. It is necessary not only to create laws, but to constantly monitor and implement means to finance the reduction, collection and recycling of ISW, incineration and proper disposal of waste that cannot be incinerated. And that these deliberations may be under the attention of one or more regulatory agencies, with the necessary powers to enforce laws, to regulate implementation and to enforce the compliance of reverse logistics management.

\section{CONCLUSIONS}

The National Policy on Environmental Education must reach the academic community and all social actors, whether through environmental institutions, governmental or not. Therefore, it is suggested that municipalities' rural managements implement inorganic solid waste management short courses for farmers. On the other hand, we are aware that it is not possible to require only small farmers to develop a management plan for their properties if they do not have adequate knowledge about PNRS.

Environmental Defense Agencies should encourage sectoral agreements between those responsible for the waste generation chain and determine the preparation and implementation of the reverse logistics plan for both fertilizer packaging and veterinary drugs.

Thus, environmental education should be the way to succeed in the intervention of society and the public power regarding the environment in rural areas, transforming the citizen in an active part of this chain, as occurs in international experiences. Therefore, it is necessary to have the interaction between the rural producer, the supplier, the public power and society in general. Without a solid alliance between these sectors, what will endure in the future is the permanence of the same difficulties that are faced today with regard to the disposal of solid waste.

\section{ACKNOWLEDGMENTS}

The authors would like to thank the Research Support Foundation of Goiás State (FAPEG), the National Foundation for the Development of Private Higher Education (FUNADESP/UniEVANGÉLICA), and the Research and Scientific Production Scholarship Program (PROBIP/UEG and UniEVANGÉLICA) for the financial aid granted to us.

\section{REFERENCES}

ABIEC. Associação Brasileira das Indústrias Exportadoras de Carnes. 2018. Perfil da pecuária no Brasil. Available online: <http://www.abiec.com.br/controle/uploads/arquivos/sumario2019portugues.pdf>. Accessed on: 10 out. 2019.

BARDIN, L. Análise de conteúdo. São Paulo, SP: Almedina, 6ạ Ed., 2011. 
BRASIL. Constituição da República Federativa do Brasil. Brasília, DF: Senado, 1988.

BRASIL. Decreto Lei no 4.070, de 04 de janeiro de 2002 que regulamenta a Lei nº 7.802, de 11 de julho de 1989. Available online: <http://www.planalto.gov.br/ccivil_03/decreto/2002/d4074.htm>. Accessed on: 26 jul. 2019.

BRASIL. Lei no 12.305, de 2 de agosto de 2010. Available online: <http://www.planalto.gov.br/ccivil_03/_ato20072010/2010/lei/l12305.htm>. Accessed on: 26 jul. 2019.

BRASIL. Lei n 12.651 , de 25 de maio de 2012. Available online: <http://www.planalto.gov.br/ccivil_03/_ato20112014/2012/lei/l12651.htm>. Accessed on: 26 jul. 2019.

BRÜHL, C. A.; ZALLER, J. G. Biodiversity decline as a consequence of an inappropriate environmental risk assessment of pesticides. Frontiers in Environmental Science, v.7, article 177, 2019. DOI: 10.3389/ fenvs.2019.00177.

CANADA. Training Materials for Pesticide Applicators. Atlantic Canada Pesticide Applicator Training Manual Series. 2015. Available online: <https://www.princeedwardisland.ca/en/search/site?keys=Applicator\%20 Core\%20Training\%20Manual\&op=search\&f\%5B0\%5D=type\%3Apublication>. Accessed on: 26 jul. 2019.

CERES. Plano de Desenvolvimento Rural de Ceres, período: 2013 a 2016. Gerência de Desenvolvimento Rural, 2013.

CIDERSP. Consórcio Intermunicipal de Desenvolvimento da Região São Patrício/GO. Plano intermunicipal de gestão integrada de resíduos sólidos, 2013. Available online: <http://acessoainformacao.cidersp.go.gov.br/ cidadao/legislacao/mp/id=7>. Accessed on: 26 jul. 2019.

CONAMA. Conselho Nacional do Meio Ambiente. Resolução no 465, de 08 de dezembro de 2014. Available online: <http://www.mma.gov.br/port/conama/res/res14/Resol465.pdf.> Accessed on 26 jul. 2019.

DUDLEY, N.; ATTWOOD, S. J.; GOULSON, D.; JARVIS, D.; BHARUCHA, Z. P.; PRETTY, J. How should conservationists respond to pesticides as a driver of biodiversity loss in agroecosystems? Biological Conservation, v.209, p. 449453, 2017.

GODECKE, M. V.; TOLEDO, E. R. M. S. Logística reversa de embalagens de agrotóxicos: Estudo do caso de Pelotas/ RS. Revista Meio Ambiente e Sustentabilidade, vol. 9, n. 4, p. 220-242, 2015.

HOLFFMANN, R. Estatística para economistas. São Paulo, SP: Editora Thomson Learning, 3a Ed., 2002.

IBGE. Instituto Brasileiro de Geografia e Estatística. Censo demográfico 2010. Características da população e dos domicílios. Available online: <http://biblioteca.ibge.gov.br/visualizacao/periodicos/93/cd_2010_caracteristicas_ populacao_domicilios.pdf>. Accessed on 25 de jul. 2019.

inpEV. Instituto Nacional de Processamento de Embalagens Vazias. Relatório de sustentabilidade 2018, 2018. Available online: <https://www.inpev.org.br/Sistemas/Saiba-Mais/Relatorio/InPev_RA2018.pdf>. Accessed on: 26 jul. 2019.

inpEV. Instituto Nacional de Processamento de Embalagens Vazias. Sistema campo limpo em números. 2018. Available online: <https://www.inpev.org.br/sistema-campo-limpo/em-numeros/>. Accessed on: 26 jul. 2019.

IPEA. Instituto de Pesquisa Aplicada. Diagnóstico dos resíduos sólidos do setor agrossilvopastoril, Resíduos Sólidos Inorgânicos. Relatório de Pesquisa. Brasília, 2013. Available online: <http://repositorio.ipea.gov.br/ handle/11058/7540>. Accessed on: 26 jul. 2019. 
JURAS, I. A. G. M. Legislação sobre resíduos sólidos: exemplos da Europa, Estados Unidos e Canadá. Biblioteca Digital da Câmara dos Deputados. Centro de Documentação e Informação. 2005. Available online: < http:// bd.camara.gov.br/bd/handle/bdcamara/1043>.

JURAS, I. A. G. M. Legislação sobre resíduos sólidos: comparação da lei 12.305/2010 com a legislação de países desenvolvidos. Biblioteca Digital da Câmara dos Deputados. Centro de Documentação e Informação. 2012. Available online: <http://bd.camara.gov.br/bd/bitstream/handle/bdcamara/9268/legislacao_residuos_ilidia. pdf?sequence=4>. Accessed on 26 jul. 2019.

KLEIN, B. N.; STADT, K. J.; MISSIO, R.; PERUZZI-HAMMAD. M.; ALMEIDA-ALVES, I. Análise do impacto do uso de organofosforados e carbamatos em trabalhadores rurais de um município da região noroeste do estado do Rio Grande do Sul. Acta Toxicológica Argentina, v. 26, n. 3, p. 104-112, 2018.

MANNARINO, C. F.; FERREIRA, J. A.; GANDOLLA, M. Contribuições para a evolução do gerenciamento de resíduos sólidos urbanos no Brasil com base na experiência Europeia. Engenharia Sanitária e Ambiental, v. 21, n. 2, p. 379-385, 2016.

MET. Ministério do Trabalho e Emprego. 2018. Norma Regulamentadora NR-31: Segurança e saúde no trabalho e na agricultura, pecuária, silvicultura, exploração florestal e aquicultura. Available online: <https://enit.trabalho. gov.br/portal/images/Arquivos_SST/SST_NR/NR-31.pdf>. Accessed on: 26 jul. 2019.

MONQUERO, P. A.; INÁCIO, E. M.; SILVA. A. C. Levantamento de agrotóxicos e utilização de equipamento de proteção individual entre os agricultores da região de Araras. Arquivos do Instituto Biológico, v. 76, n. 1, p. 135139, 2009.

PERS/GO. Plano estadual de resíduos sólidos de Goiás. Available online: < http://www.meioambiente.go.gov.br/ arquivos/pers_versao_final_forum_de_residuos_solidos.pdf>. Accessed on: 26 jul. 2019.

PGIRS/CACHOEIRA ALTA. Plano de gestão integrada de resíduos sólidos de Cachoeira Alta/GO. 2014. Available online: < http://www.prefeituradecachoeiraalta.go.gov.br/wp-content/uploads/2014/07/parte-1.pdf>. Accessed on: 10 mar. 2019.

PGIRS/MINEIROS. Plano de gestão integrada de resíduos sólidos de Mineiros/GO. 2013. Available online: < www. mineiros.go.gov.br>. Accessed on: 10 mar. 2019.

PMGRS/PAULÍNIA. Plano municipal de gerenciamento de resíduos sólidos de Paulínia/SP. 2015. Available online: <http://www.paulinia.sp.gov.br/downloads/seddema/PMGIRS.pdf>. Accessed on: 26 jul. 2019.

PMGIRS/VALINHOS. Plano municipal de gestão integrada de resíduos sólidos de Valinhos/SP. 2018. Available online:<http://www.valinhos.sp.gov.br/sites/valinhos.sp.gov.br/files/comunicacao/pmgirs_2018.pdf>. Accessed on 26 jul. 2019.

SCHIMIDT, M. L. G.; GODINHO, P. H. Um breve estudo acerca do cotidiano do trabalho de produtores rurais: intoxicações por agrotóxico e subnotificação. Revista Brasileira de Saúde Ocupacional, v. 31, n.113, p. 27-40, 2006.

SILVA, J. M.; MENDES, E. P. P. Desafio dos agricultores familiares nas comunidades rurais Cruzeiro dos Martírios e Paulistas, Catalão (GO). Revista Formação Online, v. 2, n. 19, p. 32-50, 2012.

SINDAN. Sindicato Nacional da Indústria de Produtos para Saúde Animal. 2018. Estatísticas. Mercado Brasil 2018. Available online: <http://www.sindan.org.br/mercado-brasil-2018/>. Accessed on 10 out. 2019. 